\title{
Amina Saïd, Au présent du monde
}

\section{Ilaria Bruno}

\section{(2) OpenEdition}

\section{Journals}

\section{Edizione digitale}

URL: http://journals.openedition.org/studifrancesi/28173

DOI: 10.4000/studifrancesi.28173

ISSN: 2427-5856

\section{Editore}

Rosenberg \& Sellier

\section{Edizione cartacea}

Data di pubblicazione: 31 décembre 2006

Paginazione: 647

ISSN: 0039-2944

\section{Notizia bibliografica digitale}

Ilaria Bruno, "Amina Saïd, Au présent du monde », Studi Francesi [Online], 150 (L | III) | 2006, online dal

30 novembre 2015, consultato il 08 novembre 2020. URL : http://journals.openedition.org/

studifrancesi/28173; DOI : https://doi.org/10.4000/studifrancesi.28173

\section{Questo documento è stato generato automaticamente il 8 novembre 2020.}

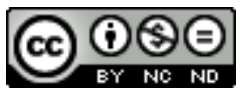

Studi Francesi è distribuita con Licenza Creative Commons Attribuzione - Non commerciale - Non opere derivate 4.0 Internazionale. 


\title{
Amina Saïd, Au présent du monde
}

\author{
Ilaria Bruno
}

\section{NOTIZIA}

AMINA SAÏD, Au présent du monde, Paris, La Différence, 2006, pp. 128.

1 Con questa raccolta la scrittrice tunisina francofona offre al lettore una riflessione sulla scrittura e sull'arte della poesia, nonché sulla vita e sul suo senso più profondo. Una lunga dedica in forma di poesia introduce un'unica sezione di circa sessanta componimenti dai toni ora più intimi e personali ora più discorsivi ed esistenziali, percorsi dalle tematiche spesso intrecciate dell' erranza e della scrittura. Poesie che parlano della forza dell'amore, dei ricordi d'infanzia, del silenzio come unica risposta ai misteri della vita, del confine labile tra realtà e sogno, rifugio privilegiato, quest'ultimo, del poeta. Il tutto reso con uno stile originale caratterizzato da numerose ellissi e antitesi, frequenti strutture anaforiche, una forte personificazione degli elementi naturali, spesso ottenuta tramite il semplice accostamento di un verbo comunemente utilizzato per gli esseri umani, infine un costante sforzo di concretezza nel tentativo di rendere "tangibile" la parola poetica. 